\title{
Smallholder farmer coping and adaptation strategies for agricultural water use during drought periods in the Overberg and West Coast Districts, Western Cape, South Africa
}

\author{
Olwethu Pili' and Bongani Ncube² (D) \\ ${ }^{1}$ Faculty of Applied Sciences, Department of Environmental and Occupational Studies, Cape Peninsula University of Technology, \\ Cape Town, South Africa \\ ${ }^{2}$ Centre for Water and Sanitation Research, Department of Civil Engineering and Geomatics, Faculty of Engineering \& the \\ Built Environment, Cape Peninsula University of Technology, Cape Town, South Africa
}

Drought is one of the most significant disasters affecting farm productivity in South Africa, with the Western Cape Province among the most affected areas. Smallholder farmers usually suffer the most due to limited resources. The study identified agricultural water use coping and adaptation strategies adopted by both crop and livestock smallholder farmers in the West Coast and Overberg districts during the recent 2015-2018 drought. Interviews were conducted with 100 smallholder farmers and 11 focus group discussions were held in the two districts. Quantitative data were analysed using the Statistical Package for Social Sciences, while qualitative data were analysed using Atlas.ti. Furthermore, the Hyogo Framework of Action was used to analyse the support that smallholder farmers had received and to understand how smallholder farmers could be effectively supported to promote the adoption of proactive strategies to deal with drought in the short and long term. It was found that the 2015-2018 drought occurred when smallholder farmers from both districts were least expecting it and were unprepared. In the West Coast District, the main coping strategies included using borehole water and selling livestock. In the Overberg District, smallholder farmers coped by purchasing fodder and transporting water from sources such as the river and dam to the farms. Several smallholder farmers in both districts did not implement any adaptation strategies. They were largely unaware of proactive agricultural water use strategies that could bolster their resilience to drought. Recommendations for the future include the adoption of drip irrigation, mulching, growing vegetables with shorter growing periods and changing planting dates. For livestock farmers, adaptation strategies include drilling boreholes and grazing management. There is also a need for early warning systems to improve the drought preparedness of smallholder farmers.

\section{INTRODUCTION}

South Africa (SA) is the $30^{\text {th }}$ most arid country in the world and is prone to droughts (Du Plessis and Schloms, 2017; Haile et al., 2019). The Western Cape (WC) Province was one of the provinces most impacted by the 2015-2018 drought (Botai et al., 2017; WCDOA, 2017), which was declared the most severe on record since the 1926-1933 drought (Botai et al., 2017; Zwane, 2019). There were heavy economic losses of approximately 5.9 billion ZAR in the agricultural sector, approximately 30000 jobs lost and export reduction of between 13 and 20\% (Botai et al., 2017; Archer et al., 2019). Opiyo et al. (2015) suggest that about 17000 cattle died of starvation.

SA has a dual agricultural system, with well-developed commercial farmers generating 95\% of agricultural output on $87 \%$ of all agricultural land, and 4 million smallholder farmers (SHFs) cultivating $13 \%$ of the agricultural land. Many farms occupied by smallholder farmers are not fully cultivated due to a lack of human capital and both physical and institutional infrastructure limiting their expansion (Hall and Aliber, 2010; Tshuma, 2014; Gwebu and Matthews, 2018). SHFs were the most affected by the 2015-2018 drought because they lacked the resources to deal with the impacts of drought (Midgley and Methner, 2016; WCDOA, 2017).

This paper adopts the South African Department of Agriculture, Forestry and Fisheries (DAFF, 2015 p. 7) definition of 'smallholder farmer', as "farmers who produce for household consumption and markets; thus farming is consciously undertaken to derive a source of income. Farming is not always the main source of income; diverse non-farming sources of income exist to sustain the household". Smallholders may have the potential to expand their farming operations and become commercial farmers. The SHFs in this study were practising rainfed agriculture, with supplementary irrigation during the dry season for crop production.

In the past, SHFs have been unable to adjust to changes in markets and policy and had to cease farming due to drought (Von Loeper et al., 2018). This was evident in the WC province during 2015-2018 where drought led to an increase in bankruptcy cases among black SHFs and forced many off the newly-reallocated farmlands (Midgley and Methner, 2016; Latham, 2016). The Strategic Plans for Smallholder Support is a South African Government programme aimed at supporting SHFs. One of its objectives includes coordinating support activities to increase the production of 15000 new and existing SHFs and also improving SHF access to extension services and training, thereby developing a complete framework outlining links for support services towards smallholders (DAFF, 2013).

\section{CORRESPONDENCE}

Bongani Ncube

EMAIL

ncubeb@cput.ac.za

\section{DATES}

Received: 4 September 2020

Accepted: 12 January 2022

\section{KEYWORDS}

crops

drought preparedness

livestock

resilience

Western Cape

\section{COPYRIGHT}

(C) The Author(s)

Published under a Creative

Commons Attribution 4.0

International Licence

(CC BY 4.0) 
However, there is also an urgent need for SHFs to devise ways to conserve agricultural water and innovate in their farming techniques (Opiyo et al., 2015; Jordaan, 2017) to be able to cope with and adapt to droughts. The term 'coping' refers to the "use of available skills, resources and opportunities to address, manage and overcome adverse conditions, to achieve basic functioning of people, institutions, organizations and systems in the short to medium term" (IPCC, 2012 p. 558). "Adaptation refers to the process of adjustment to actual or expected climate and its effects. In human systems, adaptation seeks to moderate or avoid harm or exploit beneficial opportunities. In some natural systems, human intervention may facilitate adjustment to the expected climate and its effects" (IPCC, 2012 p. 556). In this study, the term 'droughtcoping' refers to short-term interventions adopted during the drought, while 'adaptation' strategies are those interventions done to prepare for future droughts. Unfortunately, SHFs struggle to cope and adapt to drought without assistance from governmental and private institutions (Muthelo et al., 2019). This requires innovative approaches, which include knowledge-sharing and organisations and institutions to devise plans that will facilitate adaptation among SHFs (Muthelo et al., 2019). The objectives of this research were to (i) identify and describe different coping and adaptation strategies for agricultural water use adopted by SHFs in the Overberg District (OD) and West Coast District (WCD) in the WC province, and (ii) to analyse factors that hinder the SHFs' capacity to adopt strategies to cope and adapt to droughts using the principles of the Hyogo Framework of Action (UNISDR, 2015). The study was part of a larger Water Research Commission project that investigated how SHFs cope and adapt during drought periods in the Limpopo and Western Cape Provinces.

\section{METHODS}

\section{Study site}

Figure 1 shows the location of the Overberg and West Coast Districts within the Western Cape Province.

The WCD covers an area of $31119 \mathrm{~km}^{2}$ of the province and is located in a winter rainfall region (WCDM, 2018). The mean annual rainfall is relatively low across the district, and ranges from $800 \mathrm{~mm}$ in the Cederberg Mountains in the southwest, decreasing to $200 \mathrm{~mm}$ to the north, east and west and dropping to less than $100 \mathrm{~mm}$ in the far north (WCDM, 2014). Drought and the decline in rainfall threaten water resources and remain the main challenge faced in the region. Crop and livestock farming are the main livelihood activities for many individuals in the area (WCDOA, 2017; WCDM, 2018). Cultivated crops include wheat, canola, olives, grapes (table and wine), rooibos tea, fynbos, and fruit (WCDM, 2014).

The OD is located to the east of Cape Town beyond the Hottentots-Holland Mountains and covers $12239 \mathrm{~km}^{2}$ of the province (WCDM, 2018). Dryland wheat farming takes place in the southern parts of the district, while livestock production takes place across the district (DEADP and ODM, 2017). There are a few dams in the OD and people depend mainly on groundwater (River Health Programme, 2011). Drought is likely to become severe because of continued inconsistency in rainfall and changes in the climate (DEADP and ODM, 2017). Therefore, there is a need to find ways to reduce vulnerability and build resilience in the local agricultural sector by introducing timely and relevant adaptation measures (Jordaan, 2017; Maltou and Bahta, 2019).

Site selection was done in conjunction with the Western Cape Department of Agriculture (DoA). The WCD was selected as a suitable study area because it had municipalities that were already declared as disaster areas at the time of the study and it was also the driest district in 2015 (Provincial Disaster Management Centre, 2017; WCDOA, 2017). The OD was selected as a comparison site, which had not been declared a disaster area at the time of the study in 2017. However, according to DEADP and ODM (2017), even though no major droughts had been experienced in the OD in the past decade, the Overberg Municipality was among the regions that were affected by drought, with water demand increasing and threatening to surpass supply.

\section{Data collection and analysis}

The study was conducted with SHFs, as defined by the DAFF (2015), to identify known and adopted coping and adaptation

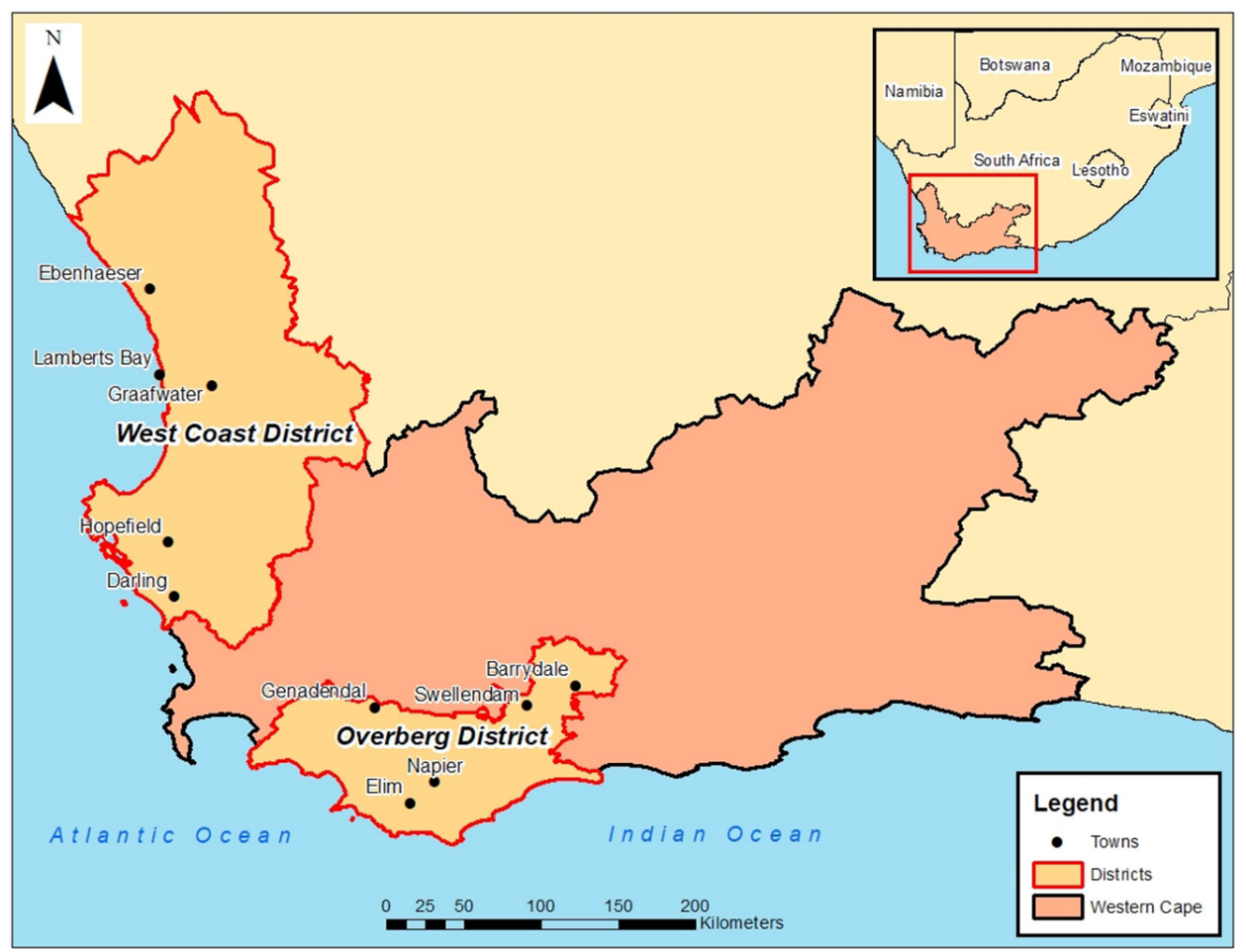

Figure 1. Map showing Overberg and West Coast Districts, Western Cape 
strategies and the factors that hinder the adoption of such strategies. A homogeneous purposive sampling was employed (Palinkas et al., 2015). The researcher identified the study participants with the help of the Western Cape DoA. The sample size for the study was $100 \mathrm{SHFs}, 50$ from the OD and 50 from the WCD, practising either crop or livestock or both crop and livestock production. Primary data were collected through face-to-face interviews using a semi-structured questionnaire. Follow-up focus group discussions (FGDs) were also conducted with the SHFs in the 11 study sites that had been selected to validate the data obtained from the interviews and to widen the scope of information gleaned (Lotich, 2011). In the OD, FGDs were conducted at Barrydale, Elim, Genadendal, Napier and Swellendam. In the WCD, the FGDs were conducted at Darling, Hopefield, Goedverwacht, Lambertsbaai, Graafwater and Ebenhaeser. During the FGDs, 10 more farmers who were not part of the original face-to-face interviews also joined the discussions. At the end of the study, 110 farmers had been consulted. Data collected on farmers' characteristics were encoded on the Statistical Package for the Social Sciences (SPSS) datasheets and analysed. Descriptive and inferential statistical analyses were used to identify percentages and frequencies. Narrative data obtained from the interviews was captured in a Word document for each farmer. All of the 100 data scripts were analysed using Atlas.ti 8 for Windows. Two projects were created on Atlas.ti, for the WCD and the OD, to be able to analyse each dataset separately. Textual codes were created, and all the documents were coded to allow the grouping of similar responses and comparisons of the documents. Furthermore, data were analysed through a codedocument table to generate frequencies. Since all the data were qualitative, a similar procedure was followed for the data obtained from the FGDs. From the literature review, gaps in the knowledge of drought and the adoption of drought strategies by SHFs from the WC province were identified.

\section{Analysis of support to smallholder farmers}

The Hyogo Framework for Action (HFA, 2005-2015) provides guidelines on how to manage and reduce disaster risks. The HFA was developed mainly to guide governments in disaster risk reduction, but the framework also has a local focus. One of the considerations of the HFA is that "both communities and local authorities should be empowered to manage and reduce disaster risk by having access to the necessary information, resources, and authority to implement actions for disaster risk reduction. Community participation is promoted through the adoption of specific policies, the promotion of networking, the strategic management of volunteer resources, the attribution of roles and responsibilities, and the delegation and provision of the necessary authority and resources" (HFA, 2005 p. 5, 7). In January 2005, 168 countries adopted the HFA to build resilience in vulnerable communities. The framework responds to the need for a comprehensive, coordinated, multi-disciplinary approach to identify and implement disaster risk reduction (DRR) strategies (UNISDR, 2013). We adopted some of the principles of the HFA to assess the support services provided to smallholder farmers by organisations and whether the support aligned with the priority areas set up in the HFA.

The HFA aims to support the efforts of regions and communities to cope better and to become more resilient to hazards that threaten their livelihoods and development which, in this case, is drought (UNISDR, 2007; UNISDR, 2013). Disaster impacts are mostly felt locally; therefore, to reduce and minimize drought impacts effectively, efforts should be made at the local level (GNDR, 2021). This can be achieved through collaboration between communities and officials (Twigg, 2015). The approach of understanding local capacities can help communities to reduce their vulnerability and build resilience towards hazards (GNDR, 2021). The HFA, therefore, helps to guide and strengthen disaster risk reduction and aids the identification of aspects that will further reduce disaster risk and build resilience.

The Priorities for Actions (PAs) under the framework help communities to assess where they stand in the implementation of disaster risk reduction and to identify possible gaps and useful next steps. However, not all risks are covered nor are all elements of disaster risk reduction. Some PAs outline basic points and processes for disaster risk reduction, while others describe more complex tasks. The PAs were used in this study to assess the support provided to SHFs and whether the support helped in drought impact reduction and if it was promoting drought resilience among SHFs. In addition, the PAs helped in identifying gaps and what could be done to help the SHFs to be resilient to future droughts and to support them more effectively.

To achieve the principal goal of the HFA, which is to reduce disaster impacts, the HFA set 5 priorities for action. In the following sections, the actions are adapted and explained, with a focus on drought as a disaster and SHFs as the community or individuals at risk.

- Priority for Action 1 (PA 1): Making disaster risk reduction a priority. This is the starting point that requires knowledge of the hazard faced, especially from a participatory process with the participation of officials and communities at risk (FAO, 2011). This requires the availability of legal frameworks for disaster risk reduction that include distributed responsibilities (UNISDR, 2009; Dlamini, 2010; UNISDIR, 2013; UNISDR, 2015).

- Priority for Action 2 (PA 2): Improving risk information and early warning. Improving hazard information and creating public awareness is an essential component in disaster reduction strategies (UNISDR, 2004). Therefore, to achieve PA 2, early warning systems (EWS) should be in place, with outreach to communities, and the warnings should be timely and understandable to the locals (UNISDR, 2007; UNISDR, 2009; UNISDR, 2015). Functional EWS distributing correct and usable information are regarded as critical components in helping SHFs to improve their adaptive capacity (Mthembu and Zwane, 2017).

- Priority for Action 3 (PA 3): Building a culture of safety and resilience. This priority for action stresses that impacts caused by disasters can only be minimised when people are well informed on the measures or strategies that they can adopt and when they are encouraged to act positively to reduce vulnerability (UNISDR, 2007). Once the risk is known, there should be a persuasion on the possibility and commitment for reducing the risk. Therefore, the local government must play a central role in empowering the community with skills, ensuring equal access to appropriate training and enhancing community capacity to cope and build disaster resilience (UNISDR, 2007; FAO, 2011; UNISDR/ITC/UNDP, 2013).

- Priority for Action 4 (PA 4): Reduce the underlying risk factors. Factors that hinder the adoption of drought-resilient strategies and that undermine SHF resilience towards drought should be reduced. Regions can help communities build resilience by investing in strategies that facilitate/ promote the reduction of risk and vulnerability. Strategies include strengthening financial instruments that provide effective insurance and credit schemes that are affordable to individuals at risk and compensate for impacts and loss to livelihood (UNISDR, 2007; UNISDR, 2009; UNISDR, 2015). Also, they promote the establishment of safety nets and the allocation of resources for SHFs to continuously enhance 
drought resilience (UNISDR, 2007). Various scholars observed that for SHFs to be able to cope and adapt to drought and to build resilience towards drought they need financial support (Harvey et al., 2018; Maltou and Bahta, 2019; Ndlovu, 2019).

- Priority for Action 5 (PA 5): Strengthening the disaster preparedness for effective response. This starts with strengthening policy and institutional capacities in national and local disaster reduction. Disaster preparedness and effective response could then be achieved by ensuring that SHFs are equipped with relevant knowledge, well-prepared and ready to act, and equipped with the knowledge and capacity for effective drought impact reduction (UNISDR, 2007). This means strengthening EWS capacity to deliver timely and clear warnings, conducting regular training, ensuring farmers take precautionary actions in response to drought warnings, relief and support, and ensuring financial reserves and contingency mechanisms are in place to rebuild livelihoods after disasters, and also build resilience (UNISDR, 2009; Jones et al., 2010; UNISDR, 2015).

\section{RESULTS AND DISCUSSION}

\section{Smallholder farmer characteristics}

Regarding gender, $74 \%$ of the interviewed SHFs in the WCD and $82 \%$ in the OD were males (Fig. 2). The average age of the SHFs was 54 years in the WCD and 52 years in the OD (the range was 18-74+ years). The majority of the farmers were between the ages of 60 and 66 years (Fig. 3), accounting for 34\% in the WCD and $26 \%$ in the OD, followed by the ages of $39-45$ years ( $18 \%$ OD and $20 \%$ WCD).

Farmers engaged in either one or more farming activities and there were eight different enterprises practised in both regions (sheep, vegetable, cattle, grain, pig, goat, vineyards, and poultry).
The most practised in the WCD was sheep production (25\%), followed by vegetables (21\%) and grain (20\%). In the OD, the most practised was vegetable farming (21\%), pig production (20\%) and sheep production (18\%). Goat production was not common in either district, even though goats are regarded as more droughttolerant than sheep and cattle (Monteiro et al., 2017). A significant number of SHFs from both districts (98\%) were employed and had more than one source of income. However, farming was the main source of income for $44 \%$ of SHFs in the WCD and $49 \%$ in the OD. This suggests that agriculture is the primary livelihood activity for SHFs in these regions.

The land size varied from 0.5 ha to 2000 ha in the OD $(<1$ ha: 6 farmers; 1-20 ha: 19 farmers; $21-100$ ha: 7 farmers and $>100$ ha; 18 farmers) and $50 \mathrm{~m}^{2}$ to 6000 ha in the WCD ( $<1$ ha: 14 farmers; 1-20 ha: 22 farmers and $>100$ ha: 14 farmers). Larger farms had combined ownership due to cooperatives and farming groups while small farms were under short lease agreements. About $48 \%$ of respondents in the WCD and $44 \%$ in the OD farmed in groups. Among those farming individually, only $38 \%$ of SHFs in the WCD and $34 \%$ in the OD involved their family members in the farming production. The results from the FGDs confirmed this, with farmers complaining that young people did not want to take part in farming because they are witnessing their parents struggle and they would rather go and look for jobs in the city than join in the struggles associated with farming. Less involvement of young people in farming presages a dire future for farming in the smallholder sector when a dearth of farmers might threaten food security. Muyambo et al. (2017) argue that when older farmers outnumber young people who are willing to farm, food security is threatened.

Regarding education, $2 \%$ of SHFs in the WCD and $6 \%$ in the OD had never been to school. Primary education had been completed by $51 \%$ of respondents in the WCD and $40 \%$ in the OD.

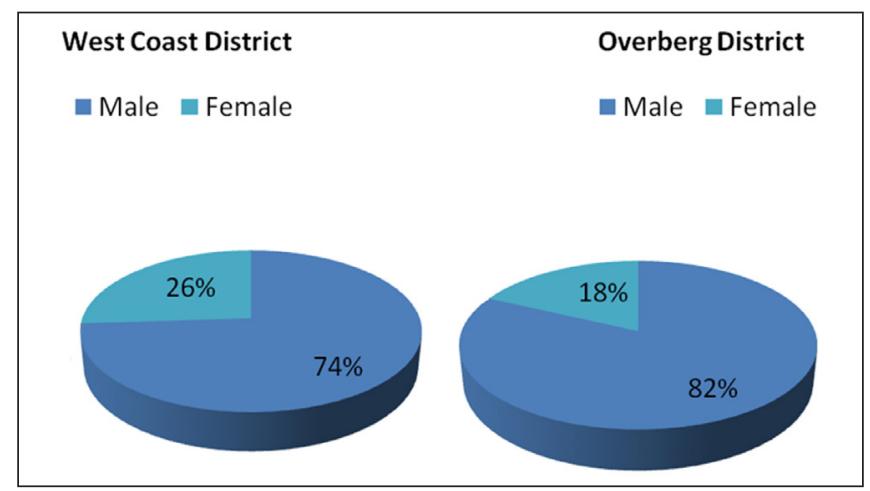

Figure 2. Smallholder farmer gender: Overberg and West Coast Districts

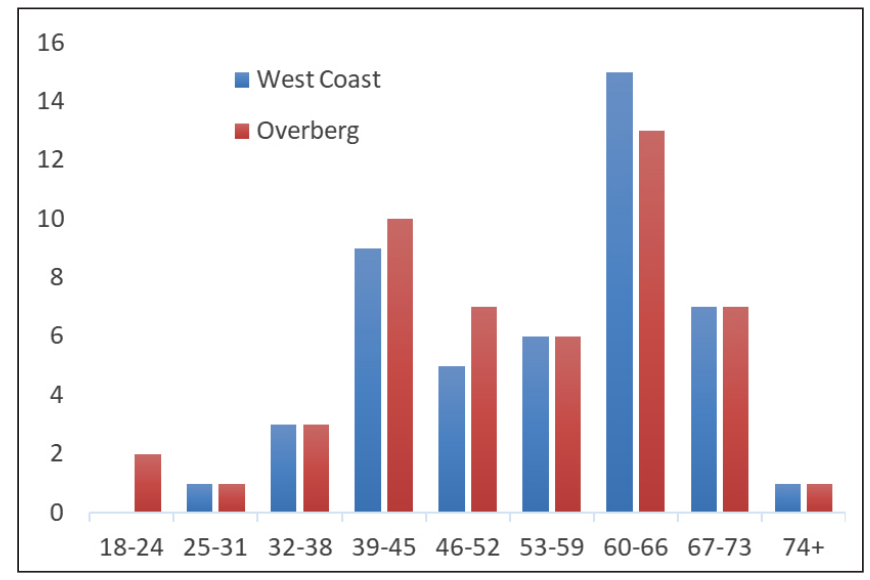

Figure 3. Smallholder farmer age distribution: Overberg and West Coast Districts 
This tells us that most farmers can read, understand, and interpret information, which could well increase their ability to cope with and adapt to drought. Formal education helps farmers to access relevant information related to drought to enhance resilience (Maltou and Bahta, 2019).

\section{Drought impacts}

During the one-on-one interviews, SHFs in both districts perceived drought as a lack of water and rainfall (34\%; $34 \%$ in WCD and OD, respectively) and a reduction in the amount of rainfall received (30\%; $21 \%$ in WCD and OD, respectively). Farmers also perceived drought based on the impacts it had on their farming production. Similar findings are reported by Ncube (2018), where farmers in the Karoo described the drought as low rainfall, a decrease in water availability, reduced grazing quality and quantity, dying vegetation and animals, food and feed shortages.

SHFs used rainfall, temperature, grazing availability, soil moisture and reservoir levels as main indicators of drought. The majority of SHFs ( $84 \%$ in the WCD; $100 \%$ in the OD) reported that they were affected by the 2015-2018 drought. Due to low rainfall, most surface water sources did not fill up. Reported impacts are shown in Fig. 4.

Livestock farmers experienced extensive livestock mortalities in both districts due to the lack of fodder and water. As a result, SHFs were forced to sell the livestock at low prices to avoid further losses. A farmer in Vredendal mentioned that sheep died while giving birth because of hunger and thirst. Similar impacts were experienced during the 2009-2011 drought in the Eden and Central Karoo Districts in the WC (Holloway et al., 2012).

An Atlas.ti analysis of drought impacts reported during FGDs in the WCD is shown in Fig. 5. The figure shows how both livestock and crop farmers experienced the drought. Farmers normally grow main crops under rainfed conditions and they also do supplementary irrigation for cash crops such as vegetables. Crop farmers experienced crop failure and others could not even plant crops due to lack of rain, and lack of water for supplementary irrigation. For example, a contract farmer in Ebenhaeser reported that, because of the limited water supply, only $14 \%$ of the planted 200-400 tons of tomatoes were reaped for Syngenta. In the OD, one SHF in Darling said, "Normally I harvest 300 big fodder bales

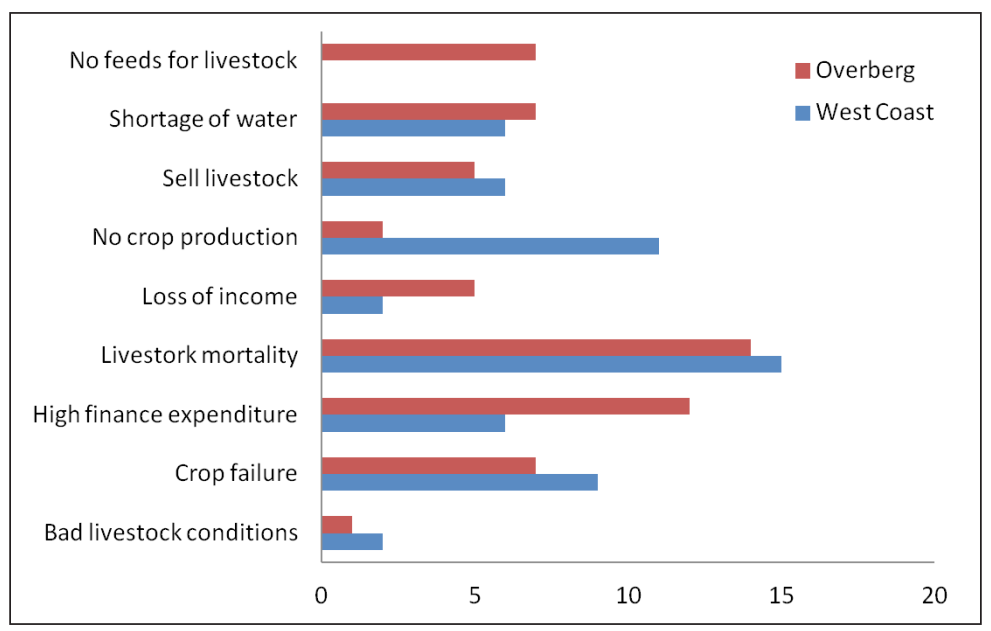

Figure 4. Drought impacts experienced by smallholder farmers 2015-2018, Overberg and West Coast Districts (open-ended question, responses of drought impacts that farmers experienced in their farming, more than one answer could be given, $\mathrm{OD} n=60, \mathrm{WCD} n=57$ )

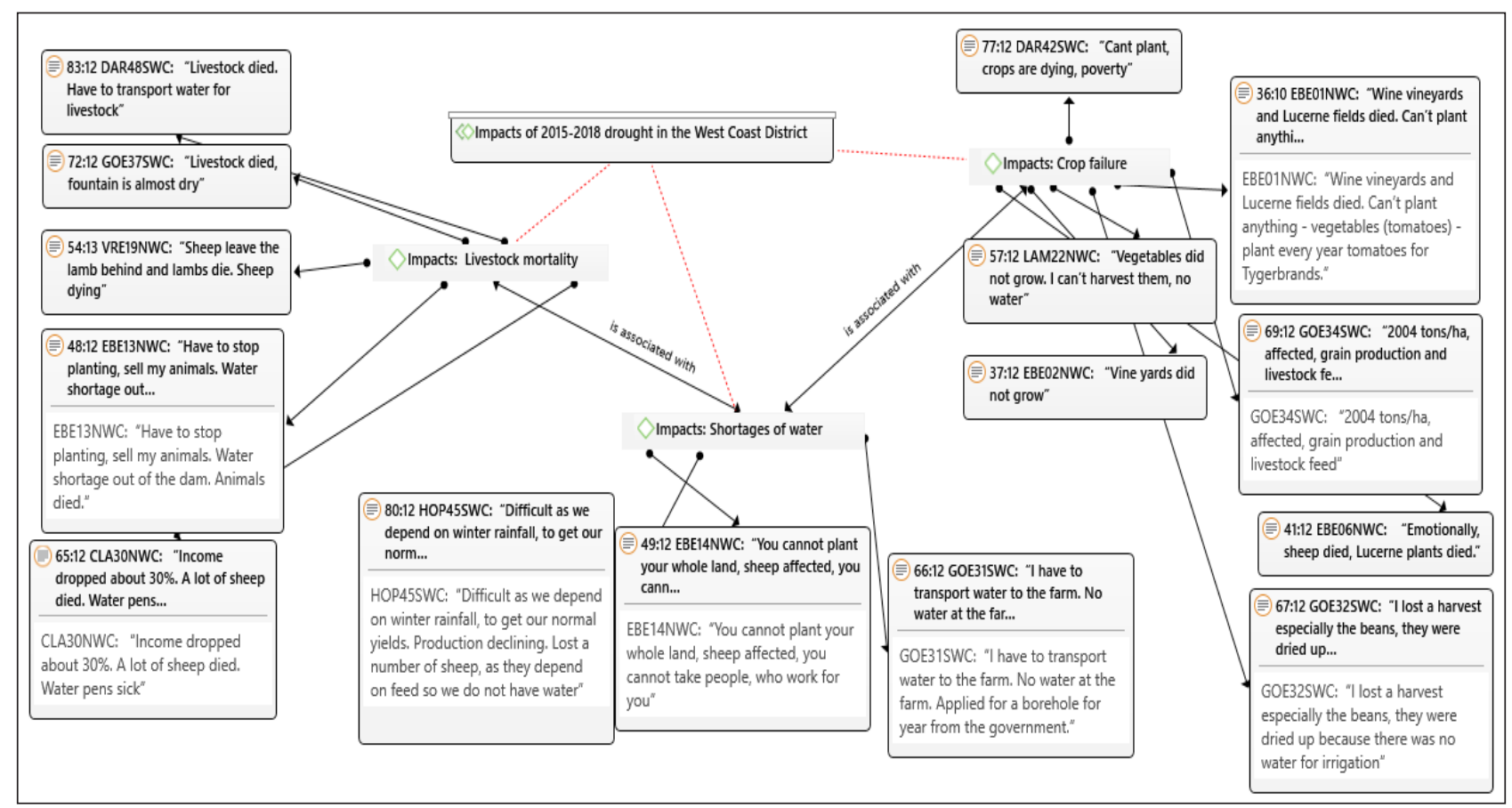

Figure 5. Atlas.ti analysis of impacts of drought in the West Coast District 
and 3000 small fodder bales, but in 2017 I harvested only 100 small bales and 20 big bales." Another farmer in Elim remarked, "I never talk about loss, but I planted 600 cauliflowers and only two were successful." Farmers in the OD spent more money than their counterparts in the WCD did because they could not grow fodder on their fields and they did not receive drought relief. They also had to pay for water. However, in the WCD too, farmers spent a lot of money on water and feed, as the following two responses attest: Vredendal: "I paid for water for irrigation purposes"; Darling: "I had to spend money on buying feed for livestock." SHFs are always hard hit during a drought (Mukheibir, 2008; Jordaan et al., 2013; Opiyo et al., 2015) and this study confirms previous findings. SHF argued that all the impacts they experienced were caused by the shortage of rain and surface water, which even led to them not cultivating all the land.

\section{COPING AND ADAPTATION STRATEGIES FOR AGRICULTURAL WATER USE}

\section{Water sources}

SHFs obtained water for agricultural use from various water sources (Fig. 6). These mainly included rivers, dams, boreholes, and municipal piped water. In the WCD, SHFs depended mainly on dams as the primary sources of agricultural water. This was attributed to farmer access to Clanwilliam Dam water (WCDOA, 2017). SHFs in the WCD suffered severely during the drought because $60 \%$ water restrictions were imposed by the municipality during the drought period, such that farmers had to find alternative water sources (WCDOA, 2016). As one SHF in the OD remarked, "Water availability was restricted during the drought". This is because in 2017 the Clanwilliam Dam only filled up to $40 \%$ after the winter rains, whereas it normally reaches overflow. Gosling (2018) confirms that farmers complained about water restrictions and that it affected their production.

In the OD, boreholes, municipal taps, and dams were the main sources of agricultural water. The utilization of groundwater in the OD was more common than in the WCD. SHFs utilising municipal water in Darling did not have water during the 20152018 drought since the municipality cut off their water supply. As a result, they depended on groundwater from an old borehole drilled by the national Department of Water and Sanitation. When dam levels dropped and river flows diminished because of prolonged drought, SHFs relying on these sources also became vulnerable. SHFs utilising groundwater survived better during the drought, as confirmed by Mthembu and Zwane (2017), who state that SHFs utilizing groundwater could reduce the impacts of drought and had better chances of survival. This was also evident in Gauteng Province, where residents were encouraged to utilise borehole water to ease the 2015-2018 drought impacts (Troskie and Johnstone, 2016). The pipeline was the main infrastructure used to deliver water from the river and dam to the farms, accounting for $47 \%$ in the WCD and $43 \%$ in the OD. However, smallholder farmers in the Lambertsbaai area pointed out that the pipeline on which they depended was narrow and exposed to the sun. Some farmers did not get water because the pressure in the pipeline was very low. Some crop farmers made use of canals $(14 \%)$, gravity irrigation (13\%), solar and electric water pumps (WCD - 8\%; OD - 21\%), drip irrigation (WCD - 8\%; OD - 2\%) and stock water systems (4\%) in the WCD and OD, respectively. SHFs that had no infrastructure transported water from various sources such as rivers and dams in containers using bakkies (small trucks/light delivery vehicles) and even wheelbarrows. These farmers accounted for $20 \%$ of respondents in the OD and $4 \%$ in the WCD. For example, in the WCD, a farmer mentioned that he used his car to transport water from the dam to the farm while another farmer mentioned that he hired transport and, if he had no money, he used a wheelbarrow. One of the SHF respondents in the OD mentioned that he had to travel approximately $18 \mathrm{~km}$ to get water from his cousin to his farm. SHFs in the Lambertsbaai area pointed out that the municipal pipeline on which they depended was too small and exposed to the sun. Some farmers did not get water because the pressure in the pipeline was very low. The use of irrigation systems such as sprinklers was not common among SHFs.

\section{Coping with drought}

The majority of SHFs reported that they had previously experienced drought since they started farming (98\% in the WCD; $88 \%$ in the OD). To cope with the 2015-2018 drought, SHFs adopted various strategies, as detailed in Fig. 7.

Using borehole water (21\%) was a coping strategy adopted by both livestock and crop farmers. However, some crop farmers reported that the water from the boreholes was too saline and could not be used for irrigation purposes. Other coping strategies for livestock farmers in the WCD included selling livestock (21\%). Purchasing water (18\%) was adopted by both livestock and crop farmers because of water shortages for irrigation and for livestock to drink. In the OD, SHFs were forced to purchase fodder to cope with the drought $(34 \%)$. SHFs also coped by transporting water from rivers or dams (27\%) using containers on wheelbarrows or hiring transport to obtain water for livestock to drink and for irrigation. SHFs in the FGDs mentioned this mode of water transportation from the river or dam for both livestock and crop

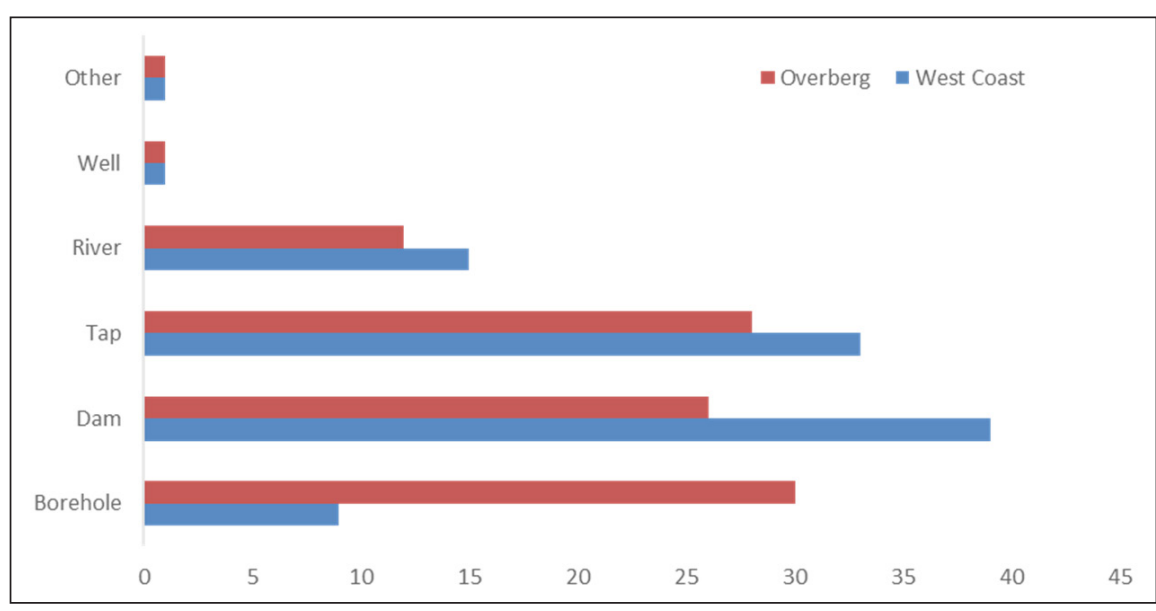

Figure 6. Smallholder farmer sources of water (open-ended question, water sources that farmers utilised for their agricultural activities, a farmer could access more than one source, OD $n=98$, WCD $n=98$ ) 


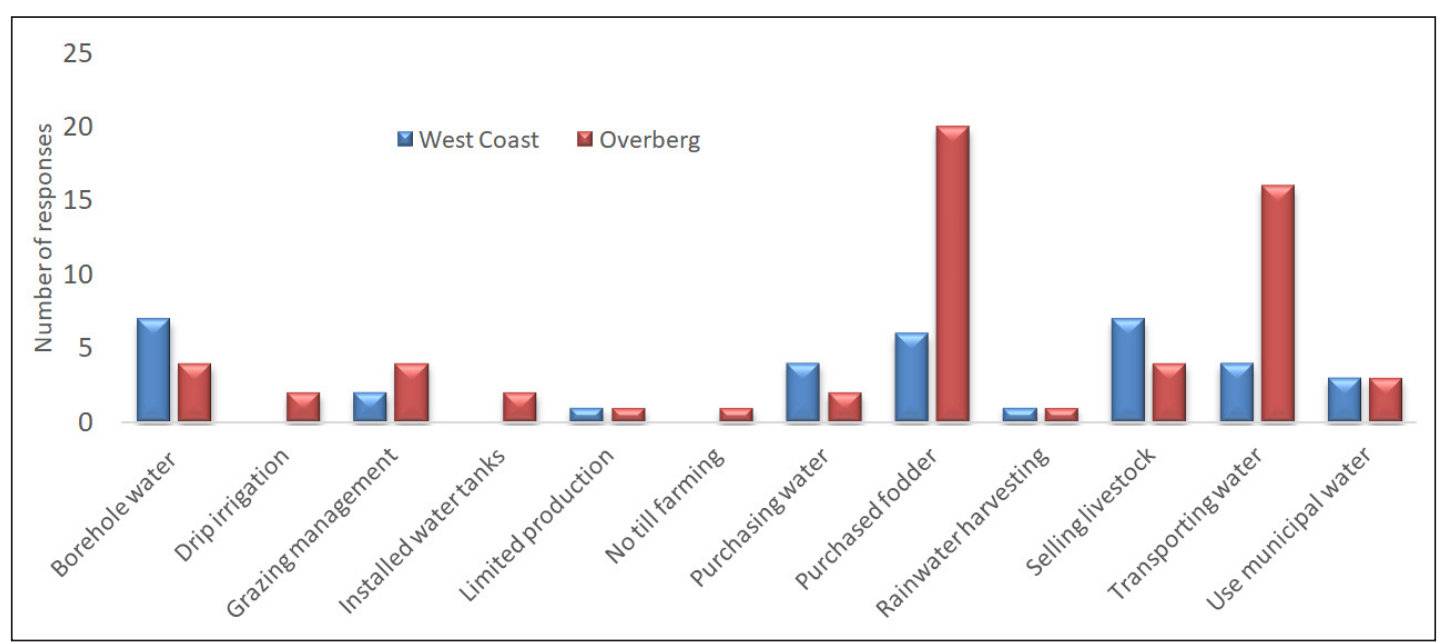

Figure 7. Smallholder farmers' agricultural water coping strategies ( $n$ is the number of responses on each mentioned coping strategy: OD $n=59$, $\mathrm{WCD} n=34)$

irrigation. During the FDGs, female respondents in the WCD reported that, for them, transportation of water with containers using wheelbarrows was difficult because the water sources were far from their farms, so they were forced to hire youth or people with cars to assist them. In the OD, one farmer said that they coped by first using water in the dams, and when it was finished they used water from boreholes, especially for livestock.

In FDG discussions in the WCD, one farmer mentioned that for them to cope during the drought they supported each other. They dug a small dam where the flowing water from the river was captured. For their livestock and irrigation, they utilised this water from the small dam. This affirms the findings of Munasib and Jordan (2011) and Mulwa et al. (2017) that farmers working in groups cope better and may be more resilient to drought than farmers farming individually. Farmers from both districts mentioned some negative coping strategies, such as scaling down crop production and selling some of their livestock. Effective coping strategies reported by various scholars (Uddin et al., 2014; Ncube, 2017; Vilakazi, 2017), such as drip irrigation (3\%), no-till farming (2\%), limiting production (2\%), and rainwater harvesting (2\%), were not commonly adopted by SHFs. Farmers mentioned that when they noticed that water availability was restricted, they had to limit production, harvest rainwater, and use drip irrigation where possible. To reduce fodder shortages livestock farmers adopted no-till planting of lucerne. In Darling, farmers mentioned that it was difficult to harvest rainwater due to the lack of storage facilities such as tanks. Rainwater harvesting was seen as both a short-term and long-term strategy.

\section{Adaptation to drought}

In the WCD and the OD, $68 \%$ and $64 \%$ of SHFs, respectively, had not implemented any adaptation strategies. Only $32 \%$ of SHFs in the WCD and 34\% SHFs in the OD had adopted long-term adaptation strategies. The results are shown in Table 1 . Only 23 farmers in the OD and 10 in the WCD had adopted strategies to cope; the rest of the farmers had not.

Seven adaptation strategies were cited by SHFs in the WCD and nine in the OD. The results show that many SHFs had not implemented any agricultural water use adaptation strategies and not all adaptation strategies mentioned were adopted by all SHFs. Storing feed was implemented in both districts. Rainwater harvesting in the OD was mentioned but the farmers indicated that not having water tanks was a challenge. Figure 8 shows the Atlas.ti analysis results on water-storing as a strategy in the OD. Storing water and the use of borehole water applies in both coping and adaptation. This depends on when the water is utilized because some farmers first use water from sources that are directly affected by the drought, such as the river and dam; borehole water is utilized when all other options run out and the water that is stored in water tanks is used as a last resort. Some farmers pointed out that the clearance of alien vegetation was one of the most effective ways of unlocking much-needed water resources and improving water availability.

Having water storage facilities such as tanks and earth dams facilitated or encouraged SHFs to adopt water-storing adaptation strategies. One farmer in Goedverwacht reported that "I harvested

Table 1. Agricultural water use drought adaptation strategies implemented by smallholder farmers

\begin{tabular}{ll}
\hline West Coast & Overberg \\
\hline Stored fodder (7) & Stored fodder (7) \\
Installed water tanks (2) & Rainwater harvesting (4) \\
Rainwater harvesting (1) & Moved livestock to secure areas (1) \\
Moved livestock to secure areas (1) & Insurance (2) \\
Limited production of high water demanding crops (1) & Conservation farming (1) \\
Used limited water (1) & Alien vegetation clearance (2) \\
Adjusted livestock herd (1) & Savings (2) \\
& Sold livestock and changed breeds (1) \\
& Drilled borehole (3) \\
\hline
\end{tabular}

$(\mathrm{n})=$ number of responses per adaptation strategy cited, Overberg $\mathrm{n}=23$, West Coast $\mathrm{n}=10$ 


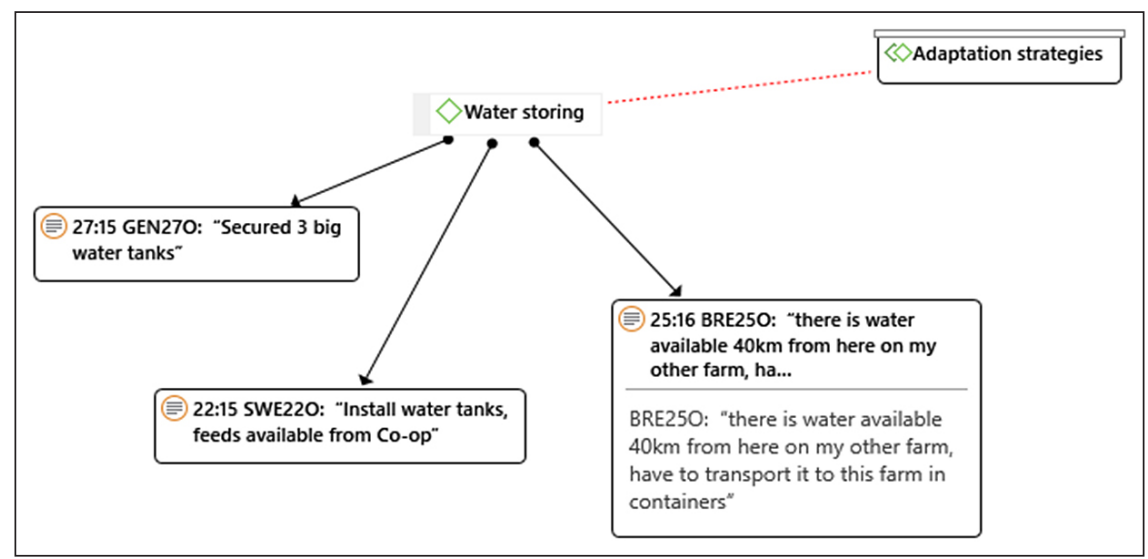

Figure 8. Overberg water-storing as an adaptation strategy

rainwater from the roof, stored it in a tank for irrigation. However, the water was not enough, so I had to scale down production so that the available water could sustain my reduced production."

Reducing livestock herds is a strategy that can also work for both coping and adaptation, depending on the duration and severity of drought, because growing the herd after the drought is considered difficult. Some farmers eventually changed to drought-tolerant breeds of livestock.

\section{Support to smallholder farmers}

Farmers were asked if they received support during the drought period. About $92 \%$ of farmers in the WCD and $56 \%$ in the OD reported having received support from different organisations. To understand whether this support played a role or enhanced resilience to drought, farmers were asked to specify the kind of support provided. Table 2 shows the results of types of support SHFs reported to have received during the drought. However, from the farmers who claimed to have received support, not all farmers specified what kind of support they received.

The provision of fodder for livestock in the form of drought relief was the main support offered during the drought in the WCD, while in the OD no such relief was offered since the area was not declared a disaster area at the time. However, all the respondents in the OD reported drought impacts similar to those experienced in the WCD. Support relating to agricultural water use included the supply of water tanks (implements), provision of water and financial support. However, there were only four positive responses in the WCD and eight in the OD for such support. During FGDs, respondents in Genadendal reported that some farmers had received tanks and fencing. In Barrydale, respondents were not in agreement because support was unevenly distributed. Some SHFs

Table 2. Support offered to smallholder farmers during the 2015-2018 drought

\begin{tabular}{ll}
\hline West Coast & Overberg \\
\hline Advisory services (1) & Chemicals (1) \\
Provision of fodder (30) & Finances (1) \\
Implements (3) & Implements (4) \\
Livestock medicine (1) & Livestock medicine (2) \\
Seeds (1) & Seeds (1) \\
Water (1) & Water (3) \\
\hline
\end{tabular}

This was an open-ended question. Numbers in brackets represent responses given by farmers per support cited, Overberg $n=13$, West Coast $\mathrm{n}=37$. Positive responses related to water: WCD:Implements 3 and Water $1=4$, OD: Water 3, Implements 4 and Finances $1=8$. indicated that no one helped them, while others were helped by the DoA with advice. Three farmers received livestock and one respondent received livestock fodder. In the WCD, respondents in Ebenhaezer mentioned having been supported by different organisations, including the DoA who offered advice, training, implements and seedlings, finance, and veterinary services. Those supported by the national Department of Water and Sanitation received water infrastructure, a dam and provision of water through the canal. The Cape Agency for Sustainable Integrated Development in Rural Areas (CASIDRA) provided drought relief for some farmers. SHFs from both districts reported that support was unevenly distributed, with some SHFs reporting they had received nothing from any organisation.

Often, SHFs do not have access to facilities such as credit and grants, exacerbating their vulnerability (Turpie and Visser, 2013). However, this was not the case in this study as $84 \%$ of the SHFs reported having access to credit facilities. However, during the FGDs, among the $12 \%$ with no credit access, some reported that they did not know whom to contact, which was surprising. This is because during one-on-one interviews the majority of the $12 \%$ with no access to credit reported the main issue as being unable to meet loan requirements. Since they were on short-term leases, production was generating too little income and the loan interest was said to be high. SHFs who claimed they had access but could not borrow money cited various reasons, including challenges that their production generated insufficient income to satisfy the bank. On the other hand, SHFs who had no problem with credit borrowed money from cooperatives, commercial banks, and other unspecified sources. The money was paid back at a certain interest rate per agreement with the credit provider. Smallholders emphasised that they willingly borrowed more money to help them buy infrastructure such as water tanks and water reticulation equipment to improve their productivity. In the OD, SHFs who had access to funds in theory but were not borrowing mentioned that their productivity was small and they could not afford interest rates. Also, SHFs indicated that it would be better if they received the money in the form of grants.

\section{Factors that hindered the adoption of adaptation strategies}

Farmers who did not put any plans in place for the drought mentioned several factors that hindered them from adopting adaptation strategies. Amongst the factors, farmers mentioned a lack of awareness ( $80 \%$ in the WCD and $62 \%$ in the OD) of the actual occurrence of the drought, and most SHFs were caught unprepared. In Darling in the WCD, the municipality shut off the water supply because of the drought, while SHFs were not even aware of the drought in the area. Other factors mentioned by the 
farmers included lack of finance and lack of water in the WCD, while in the OD they included lack of farming resources such as finance. Farmers in Hopefield said they were not equipped to adopt adaptation strategies.

SHFs reported that they attended farmers' events conducted by agricultural extension officers in enhancing their farming skills. These included farmers' days, information sessions, demonstration sessions, training, and workshops. However, the SHFs reported that there was a lack of drought-related training or workshops that could help them to cope and adapt. During FGDs in the OD, some farmers from Elim, Barrydale and Genadendal reported that these events were no longer taking place. Respondents in Elim mentioned that they had farmers' events two years back. Meanwhile, respondents from Barrydale indicated that "We have been having events every month but we do not have water, we cannot do anything with the knowledge only, we have stopped projects until we sort the water issue." Farmers felt that knowledge alone could not help them if not accompanied by necessary resources that could help them to cope and adapt to drought. Besides attending these events, SHFs in the WCD (70\%) and the OD (50\%) had received some form of training. No farmers reported training on drought-related matters. According to Maltou and Bahta (2019), formal training may help SHFs to acquire the adaptive capacity to respond flexibly to disasters.

\section{IMPLICATIONS OF THE RESULTS}

\section{Implications for smallholder farmers}

It is predicted that droughts will increase in severity and have devastating impacts (IPCC, 2014; Naumann et al., 2018), and SHFs are always hard-hit during droughts (Jordaan et al., 2013; Opiyo et al., 2015). This study confirms previous findings, as farmers reported several drought impacts caused by the 20152018 drought. Farmers from both districts were dependent on water sources that were directly affected by the drought, such as rivers, dams, and municipal supplies. In the $\mathrm{WC}$, water reservoirs were below 30\% capacity in 2017 (Botai et al., 2017). These impacts imply that there is a need to proactively cope and adapt to drought, given that drought impacts are expected to persist in both livestock and crop production in SA (DAFF, 2016).

Effective coping strategies for crop farmers supported by literature include making use of borehole water, drip irrigation, no-till farming and rainwater harvesting (Uddin et al., 2014; Ncube, 2020; Vilakazi, 2017); these were rarely adopted by SHFs from both districts. This was because such strategies are costly, farmers had limited finances and the income generated was not enough to adopt such strategies, because drilling boreholes is costly and storing water requires water storage facilities such as tanks. However, none of these was adopted by SHFs in the WCD or OD. Farmers were not well equipped and some had no knowledge of many strategies. Similarly, known adaptation strategies were not practised, such as conservation tillage, using improved agricultural inputs and drip irrigation (O'Farrella et al., 2009; Ringler et al., 2011; Komba and Muchapondwa, 2012; Falco and Veronesi, 2014; Bocher, 2016; Adusumilli and Wang, 2018). This was due to limited farming resources and finances. Well-known adaptation strategies for crop production were lacking, such as changing crop varieties, crop rotation, shifting planting dates, practising soil and water conservation tillage, using improved agricultural inputs, and irrigation (O'Farrella et al., 2009; Ringler et al., 2011; Komba and Muchapondwa, 2012; Falco and Veronesi, 2014; Kom et al., 2020; Mukheibir, 2008; Ncube and Lagardien, 2015; Ubisi, 2017; Zwane, 2019; Ncube, 2020).

Only $32 \%$ of SHFs in the WCD and $34 \%$ in the OD had implemented any adaptation strategies in livestock farming.
Reported adaptation strategies by SHFs from both districts are widely supported in the literature, such as fodder storage, adjusting livestock herds, moving livestock to places with secure grazing and water, insurance, conservation farming, alien clearance and rainwater harvesting (Elum et al., 2017; Muthelo, 2019; Ndlovu, 2019, Zwane, 2019). However, 68\% of SHFs in WCD and 66\% in the OD had no plans in place to implement these strategies. The SHFs mentioned factors that limited their ability to plan, the primary one being the lack of early warnings on the occurrence of the drought. Others included lack of resources such as water storage facilities and lack of finances. During the FGDs, SHFs mentioned that they were not fully equipped to employ some strategies, so skills training could help them. Finances were insufficient to employ some strategies, such as purchasing fodder, purchasing water tanks for water storage and drilling boreholes. Access to credit did not play a role in helping SHFs to cope and adapt better because of the high-interest rates. Taking out insurance was adopted by some farmers in WCD but this strategy only serves as a cash cushion to help farmers during drought periods to cope, adapt better, recover from unforeseen impacts and maintain their livelihoods (Kahan, 2013; Greatrex et al., 2015). SHFs reported that they could not take credit or insurance because of high-interest rates. Mutaqin and Usam (2019) confirm that insurance premiums are usually not affordable for SHFs.

In the $\mathrm{OD}$ and the WCD, government and farming institutions were aware of the impacts of drought on SHFs and mindful of the urgency to support them. However, the drought caught both farmers and officials unprepared because some farmers reported that drought relief came very late when they had already experienced losses. To support SHFs during drought, the South African Government provides drought relief in the form of fodder (Bahta et al., 2016), but there were no financial reserves and contingency mechanisms in place to support an effective response for SHFs. The fodder supply support was insufficient and not always readily available. Some farmers had to wait, while some farmers used savings and sold some of their produce to mitigate further losses. Farmers in the OD did not receive drought relief as the district had not been declared a disaster area at the time interviews were conducted. The study took place between September 2017 and April 2019.

The recurrence of severe drought demonstrates the need to reduce drought impacts through the development of drought resilience strategies (Jordaan, 2017). Fodder supply does not promote the adoption of agricultural water strategies and does not build drought resilience among SHFs, but rather promotes reliance on government during drought (StatsSA, 2012; Ngaka, 2012; Gerber and Mirzabaev, 2017; Muyambo et al., 2017). When support is delayed or not provided, SHFs are left with limited or no options to sustain their production (Mthembu and Zwane, 2017). This was evident when SHFs from OD mentioned that they could do nothing because the government did not help them.

\section{Effectiveness of support to smallholder farmers}

Disaster risk reduction was not a priority for protecting smallholder farmers in the research sites, therefore the requirements of Priority for Action 1 ('Making disaster risk reduction a priority') were lacking. Declaration of drought disasters is a process that takes place at the national level through the Disaster Management Act, No. 57 of 2002. Farmers did not receive any support unless their district was declared a disaster area. There was no formal strategy used by organisations at the district and local level to effectively help smallholder farmers during the drought unless a district had been declared a disaster area. There was limited knowledge of the drought disaster and there was no participatory discussion between officials and communities at risk to get a common understanding of the drought. 
Drought occurrence in both districts demonstrates a lack of effective early warning systems. Farmers who received information said it was about climate change and they were unable to interpret the information to imply that a drought was pending. The HFA points out that warnings should be accompanied by regular training on how to implement strategies and ensure farmers take precautionary actions in response to drought warnings (UNISDR, 2009; Jones et al., 2010; UNISDR, 2015). Priority for Action 2 on 'Improving risk information and early warning' was, therefore, partly implemented, but it was not effective because the farmers did not understand the implications of climate change information that was shared with them.

Agricultural Extension Officers conducted various events to assist SHFs in enhancing their farming skills. However, smallholder farmers said such events were no longer taking place in some areas. Some farmers remarked that they used to learn a lot from those events, and added that they would appreciate help to aid in enhancing their adaptive skills, as some acknowledged that they were not fully equipped to adopt some strategies. This implies an urgent need to resume training that will help farmers in their farming and adopting drought strategies. The Department of Agriculture played a role in empowering the farmers with skills but it was also not enough to prepare the farmers for the droughts. Priority for Action 3 ('Building a culture of safety and resilience'), was therefore partly implemented, although it was not focused on reducing drought risk.

To build resilience emergency funds, preparedness strategies and recovery schemes should be in place in districts, and both authorities and SHF should be ready to act (UNISDR, 2007). The centralisation of the drought declaration process made it difficult to 'Reduce the underlying risk factors' of drought at the district level. There were no funds reserved for drought management, yet farmers from both districts were in urgent need of fodder and financial support at the start and during the drought. Farmers in WCD received some assistance in the form of fodder, but the ones in OD did not, because the district had not been declared a disaster area. Farmers used their savings and others stopped production since there was no readily available support. Maltou and Bahta (2019) attest that support offered to SHFs should assist farmers to reduce impacts, adapt, and better prepare for future droughts. Unfortunately, this was not the case in the study area. Previous studies in the province also reported the need for drought preparedness (Ncube and Lagardien, 2015).

'Strengthening the disaster preparedness for effective response' happens at the national level in South Africa. Drought policy development and implementation take place at the national level with limited participation from affected communities. In this study, Barrydale smallholder farmers suffered losses right from the start of the drought, but because Overberg District had not been declared a disaster area the farmers did not receive any assistance until much later, when it was too late.

\section{CONCLUSIONS AND RECOMMENDATIONS}

The 2015-2018 drought was a disaster that seemed to have caught everyone unawares, from the national level to the local level. This was an indication that drought preparedness is not a priority in South Africa. Unfortunately, the drought resulted in huge production losses in the Overberg and West Coast Districts, especially for smallholder farmers who lacked resources (Fanadzo et al., 2021). This study identified that the adoption of drought adaptation strategies such as drilling boreholes, conservation farming, insurance and installing water storage tanks was limited. Factors that hindered farmers from adopting the strategies were also identified. A significant number of SHFs reported that they had no plans in place (68\% in the WCD; $64 \%$ in the OD). It was noted that the respondents' inability to cope and put adaptation plans in place for the drought was due to a lack of access to resources (finance, storage facilities, transport), lack of timely information and lack of skills to adopt such strategies.

SHF farming generated insufficient net returns to adopt strategies such as drilling boreholes and installing water tanks. Although financial support was available in form of credit, it was not an ideal option due to high-interest rates. Therefore, the financial and technical support as advised by the HFA was a huge gap. Support in the form of grants was mostly preferred by SHFs as they would not need to pay back the funds. The SHFs in this study said government drought relief support in the form of fodder supply was insufficient and not accessible to everyone, especially at the start of the drought, and they had to use their savings to prevent major losses. While training from the government was not done in all areas, some farmers indicated that they had benefitted from training, even though it was not specifically training on drought preparedness.

SHFs play a critical role in reducing family poverty, supplying surplus food to the local market, and creating local jobs. To help these farmers survive, there is a need to improve support (DAFF, 2013), especially during disaster periods. Therefore, the guidelines of the HFA for the planning and implementation of strategies are recommended. However, while the HFA is a good framework, the top-down approach that it uses is a challenge as it limits the participation of local authorities and participating communities in developing effective policies and strategies. The UNISDR (2009) also argues that, although the policies and frameworks are important, they do not necessarily translate to effective disaster reduction. Principles need to be applied and necessary resources made available.

Departments such as the DoA and other relevant organisations should consider training SHFs and providing resources that will improve drought knowledge and enhance their coping and adaptation capacities. Training should be implemented to help SHFs in decision-making during drought and in preparation for drought. Also, in terms of providing support, officials should work together to efficiently and equitably deliver the support to avoid duplication of efforts.

The focus of this study was only on SHFs. Future studies should explore the effectiveness of the identified coping and adaptation strategies for all types of farmers, including subsistence and commercial farmers.

\section{ACKNOWLEDGEMENTS}

The research was funded by the South Africa Water Research Commission (Project K5/2716/4). The student bursary was partly funded by the Cape Peninsula University of Technology.

\section{AUTHOR CONTRIBUTIONS}

The manuscript is an output from Ms Pili's Masters thesis. She carried out the following activities: collected the data through farmer interviews; performed data analysis and created the tables and graphs; wrote the paper.

The manuscript is part of a research project that Dr Ncube was leading. She carried out the following activities: conceived and designed the research project; was the project leader and principal investigator in the project; was the supervisor for Ms Pili's Master's degree; collected the data, led all the focus group discussions; guided the writing and editing of the manuscript; did the final editing of the manuscript.

\section{ORCIDS}

\section{Bongani Ncube}

https://orcid.org/0000-0003-1936-2768 


\section{REFERENCES}

ARCHER E, LANDMAN W, MALHERBE J, TADROSS M and PRETORIUS S (2019) South Africa's winter rainfall region drought: A region in transition? Clim. Risk Manage. 25 100188. https://doi. org/10.1016/j.crm.2019.100188

BAHTA YT, JORDAAN A and MUYAMBO F (2016) Communal farmers' perception of drought in South Africa: Policy implication for drought risk reduction. Int. J. Disaster Risk Reduct. 20 39-50. https://doi.org/10.1016/j.ijdrr.2016.10.007

BOTAI CM, BOTAI JO, DE WIT JP, NCONGWANE KP and ADEOLA AM (2017) Drought characteristics over the Western Cape Province, South Africa. Water. 9 (876) 1-16. https://doi.org/10.3390/w9110876

DAFF (Department of Agriculture Forestry and Fisheries, South Africa) (2013) Strategic Plan for Smallholder Support 2011-2014/15. DAFF, Pretoria.

DAFF (Department of Agriculture Forestry and Fisheries, South Africa) (2015) Integrated Agriculture Development Finance Policy Framework (IADFP) for Smallholder Farmers. DAFF, Pretoria.

DAFF (Department of Agriculture Forestry and Fisheries, South Africa) (2016) Annual Report 2015/2016: Vote 24 Agriculture, Forestry and Fisheries. DAFF, Pretoria.

DEADP and ODM (Western Cape Department of Environmental Affairs and Development Planning \& Overberg District Municipality) (2017) Overberg climate change response framework. https://odm. org.za/sites/default/files/documents/Overberg\%20Climate\%20Chan ge\%20Response\%20Framework.pdf (Accessed 22 May 2018).

DLAMINI TR (2010) Collective farming: elements constituting an effective agricultural co-operative, the case of three co-operatives in the Umgungundlovu district. Published $\mathrm{PhD}$ dissertation, University of KwaZulu-Natal.

DU PLESSIS JA and SCHLOMS B (2017) An investigation into the evidence of seasonal rainfall pattern shifts in the Western Cape, South Africa. J. S. Afr. Inst. Civ. Eng. 59 (4) 47-55. https://doi.org/ 10.17159/2309-8775/2017/v59n4a5

ELUM ZA, MODISE DM and MARR A (2017) Farmer's perception of climate change and responsive strategies in three selected provinces of South Africa. Clim. Risk Manage. 16 246-257. https://doi.org/10 1016/j.crm.2016.11.001

FALCO SD and VERONESI M (2014) Managing environmental risk in presence of climate change: The role of adaptation in the Nile Basin of Ethiopia. Environ. Resour. Econ. 57 553-577. https://doi. org/10.1007/s10640-013-9696-1

FANADZO M, NCUBE B, FRENCH A and BELETE A (2021) Smallholder farmer coping and adaptation strategies during the 2015-18 drought in the Western Cape, South Africa. Phys. Chem. Earth A/B/C, 124 (Part 1) 102986. https://doi.org/10.1016/j.pce.2021.102986

FAO (Food and Agriculture Organization) (2011) Climate Change Adaptation and Disaster Risk Management in Agriculture. Priority Framework for Action 2011-2020. FAO, Rome.

GERBER N and MIRZABAEV A (2017) Benefits of action and costs of inaction: Drought mitigation and preparedness - a literature review. Working Paper, January 2017. Integrated Drought Management Programme, Bonn. 1-25. https://doi.org/10.1201/b22009-7

GNDR (Global Network of Civil Society Organisations for Disaster Reduction) (2021). Local leadership for global impact. URL: https:// strategy.gndr.org/principles/ (Accessed 7 June 2021).

GOSLING M (2018) Boorde en wingerde krimp. Die Burger 23 March 2018,4 .

GREATREX H, HANSEN J, GARVIN, S, DIRO R, LE GUEN M, BLAKELEY S, RAO K and OSGOOD D (2015) Scaling up index insurance for smallholder farmers: Recent evidence and insights. CCAFS Report No. 14. CGIAR Research Program on Climate Change, Agriculture and Food Security (CCAFS), Copenhagen, Denmark.

GWEBU JZ and MATTHEWS N (2018) Metafrontier analysis of commercial and smallholder tomato production: A South African case. S. Afr. J. Sci. 114 (7-8) 55-62. https://doi.org/10.17159/sajs. 2018/20170258

HAILE GG, TANG Q, SUN S, HUANG Z, ZHANG X and LIU X (2019) Droughts in East Africa: Causes, impacts and resilience. Earth-Sci. Rev. 193 146-161. https://doi.org/10.1016/j.earscirev.2019.04.015

HALL R and ALIBER M (2010) The case for re-strategising spending priorities to support small-scale farmers in South Africa. Working Paper No. 17. Institute for Poverty, Land and Agrarian Studies (PLAAS), University of the Western Cape.
HARVEY CA, SABORIO-RODRÍGUE, M, MARTINEZ-RODRÍGUEZ MR, VIGUERA B, CHAIN-GUADARRAMA A, VIGNOLA R and ALPIZAR F (2018) Climate change impacts and adaptation among smallholder farmers in Central America. Agric. Food Secur. 7 (1) 57. https://doi.org/10.1186/s40066-018-0209-x

HOLLOWAY A, FORTUNE G, ZWEIG P, BARRETT L, BENJAMIN A, CHASI V and DE WAAL J (2012) Eden and Central Karoo drought disaster 2009-2011 The scramble for water. Report No. LG 10/2011/2012, July 2012. Stellenbosch University, Stellenbosch.

HYOGO FRAMEWORK FOR ACTION 2005-2015 (2005) Building the Resilience of Nations and Communities to Disasters. International Strategy for Disaster Reduction. World Conference on Disaster Reduction, 18-22 January 2005, Kobe, Hyogo, Japan.

IPCC (Intergovernmental Panel on Climate Change) (2012) Glossary of terms. In: Field CB, Barros V, Stocker TF, Qin D, Dokken DJ, Ebi KL, Mastrandrea MD, Mach KJ, Plattner G-K, Allen SK, Tignor M and Midgley PM (eds.) Managing the Risks of Extreme Events and Disasters to Advance Climate Change Adaptation. A Special Report of Working Groups I and II of the Intergovernmental Panel on Climate Change (IPCC). Cambridge University Press, Cambridge, UK, and New York, NY, USA. 555-564.

IPCC (Intergovernmental Panel on Climate Change) (2014). Summary for policymakers. In: Field CB, Barros VR, Dokken DJ, Mach KJ, Mastrandrea MD, Bilir TE, Chatterjee M, Ebi YL, Estrada YO, Genova RC, Girma B, Kissel ES, Levy AN, MacCracken S, Mastrandrea PR and White LL (eds) Climate Change 2014: Impacts, Adaptation, and Vulnerability. Part A: Global and Sectoral Aspects. Contribution of Working Group II to the Fifth Assessment Report of the Intergovernmental Panel on Climate Change. Cambridge University Press, Cambridge, UK and New York, USA. 32 pp.

JONES L, LUDI E and LEVINE S (2010) Towards a characterisation of adaptive capacity: a framework for analysing adaptive capacity at the local level. December 2010. Overseas Development Institute, London. 1-8.

JORDAAN AJ (2017) Vulnerability, adaptation to and coping with drought: The case of commercial and subsistence rain fed farming in the Eastern Cape. WRC Report No. TT 716/1/17. Water Research Commission, Pretoria.

JORDAAN AJ, SAKULSKI D and JORDAAN AD (2013) Interdisciplinary drought risk assessment for agriculture: The case of communal farmers in the Northern Cape Province, South Africa. S. Afr. J. Agric. 41 44-58.

KAHAN D (2013) Managing risk in farming. Farm Management Extension Guide 3. Food and Agriculture Organization of the United Nations, Rome. 120 pp.

KOM Z, NETHENGWE NS, MPANDELI NS and CHIKOORE H (2020) Determinants of small-scale farmers' choice and adaptive strategies in response to climatic shocks in Vhembe District, South Africa. GeoJournal. 3 1-24. https://doi.org/10.1007/s10708-020-10272-7

KOMBA C and MUCHAPONDWA E (2012) Adaptation to climate change by smallholder farmers in Tanzania. Working Paper 299, July 2012. Economic Research Southern Africa, Cape Town. 32 pp.

LATHAM D (2016) Newly empowered black farmers ruined by South Africa's drought. Inter Press Service 30 Jul 2016.

LOTICH P (2011) What is the purpose and advantages of focus group interviews? URL:https://www.socialmediatoday.com/content/whatpurpose-and-advantages-focus-group-interviews (Accessed 13 May 2020).

MALTOU R and BAHTA YT (2019) Factors influencing the resilience of smallholder livestock farmers to agricultural drought in South Africa: Implication for adaptive capabilities. Jàmbá: J. Disaster Risk Stud. 11 (1) 1-7. https://doi.org/10.4102/jamba.v11i1.805

MIDGLEY S and METHNER N (2016) Climate adaptation readiness for agricultural: Drought lessons from the Western Cape, South Africa. SAIAA Policy Briefing 154, November 2016. URL: https:// saiia.org.za/research/climate-adaptation-readiness-for-agriculturedrought-lessons-from-the-western-cape-south-africa/ (Accessed 18 July 2018).

MONTEIRO A, COSTA JM and LIMA MJ (2017) Goat system productions: Advantages and disadvantages to the animal, environmental and farmer. https://www.intechopen.com/books/ goat-science/goat-system-productions-advantages-and-disadvantag es-to-the-animal-environment-and-farmer (Accessed 17 May 2019). 
MTHEMBU NN and ZWANE EM (2017) The adaptive capacity of smallholder mixed-farming systems to the impact of climate change: The case of KwaZulu-Natal in South Africa. Jàmbá: J. Disaster Risk Stud. 9 (1) 1-9. http://dx.doi.org/10.4102/jamba.v9i1.469

MUKHEIBIR P (2008) Qualitative assessment of municipal water resource management strategies under climate impacts: The case of the Northern Cape, South Africa. Energy Res. Cent. 4 (33) 575-582.

MULWA C, MARENYA P and KASSIE M (2017) Response to climate risks among smallholder farmers in Malawi: A multivariate probit assessment of the role of information, household demographics, and farm characteristics. Clim. Risk Manage. 16 208-221. https://doi org/10.1016/j.crm.2017.01.002

MUNASIB A and JORDAN JL (2011) The effect of social capital on the choice to use sustainable agricultural practices. J. Agric. Appl. Econ. 43 (1379-2016-113720) 213-227. https://doi.org/10.1017/S107 $407080000417 \mathrm{X}$

MUTAQIN DJ and USAMI K (2019) Smallholder farmers' willingness to pay for agricultural production cost insurance in rural West Java, Indonesia: A contingent valuation method (CVM) approach. Risks 7 (2) 69. https://doi.org/10.3390/risks7020069

MUTHELO D, OWUSU-SEKYERE E and OGUNDEJI AA (2019) Smallholder farmers' adaptation to drought: Identifying effective adaptive strategies and measures. Water. 11 (10) 2069. https://doi. org $/ 10.3390 /$ w11102069

MUYAMBO F, JORDAAN AJ and BAHTA YT (2017) Assessing social vulnerability to drought in South Africa: Policy implication for drought risk reduction. Jàmbá: J. Disaster Risk Stud. 9 (1) 1-7. https://doi.org/10.4102/jamba.v9i1.326

NAUMANN G, ALFIERI L, WYSER K, MENTASCHI L, BETTS RA, CARRAO, H, SPINONI, J, VOGT J and FEYEN L (2018) Global changes in drought conditions under different levels of warming. Geophys. Res. Lett. 45 (7) 3285-3296. https://doi.org/ 10.1002/2017GL076521

NCUBE B (2017) Coping and adaptation strategies for agricultural water use during drought periods. WRC Report No. KV 363/17. Water Research Commission, Pretoria.

NCUBE B (2018) Insights into indigenous knowledge strategies for coping and adapting to drought in agriculture: A Karoo scenario, South Africa. Indilinga Afr. J. Indig. Knowl. Syst. 17 (1) 92-108.

NCUBE B (2020) Smallholder farmer drought coping and adaptation strategies in Limpopo and Western Cape provinces. WRC Report No. 2716/1/20. Water Research Commission, Pretoria

NCUBE B and LAGARDIEN A (2015) Insights into indigenous coping strategies to drought for adaptation in agriculture: A Karoo scenario. WRC Report No. 2084/1/15. Water Research Commission, Pretoria.

NDLOVU T (2019) Coping with drought: Reflection of communal cattle farmers in Umzingwane district in Zimbabwe. Jàmbá: J. Disaster Risk Stud. 11 (1) 1-9. https://doi.org/10.4102/jamba.v11i1.813

NGAKA MJ (2012) Drought preparedness, impact and response: A case of the Eastern Cape and Free State provinces of South Africa. Jàmbá: J. Disaster Risk Stud. 4 (1) 1-10. https://doi.org/10.4102/jamba.v4 i1.47

O'FARRELLA PJ, ANDERSONB PML, MILTONC SJ and DEAN WRJ (2009) Human response and adaptation to drought in the arid zone: Lessons from Southern Africa. S. Afr. J. Sci. 105 34-39. https://doi. org/10.1590/S0038-23532009000100018

OPIYO F, WASONGA O, NYANGITO M, SCHILLING J and MUNANG R (2015) Drought adaptation and coping strategies among the Turkana pastoralists of Northern Kenya. Int. J. Disaster Risk Sci. 6 (3) 295-309. https://doi.org/10.1007/s13753-015-0063-4

PALINKAS LA, HORWITZ SM, GREEN, CA, WISDOM JP, DUAN N and HOAGWOOD K (2015) Purposeful sampling for qualitative data collection and analysis in mixed method implementation research. Admin. Polic. Mental Health Mental Health Serv. Res. 42 (5) 533-544. https://doi.org/10.1007/s10488-013-0528-y

PROVINCIAL DISASTER MANAGEMENT CENTRE (2017) Annual Report, 1 April 2016 - 31 March 2017. URL: https://www.westerncape. gov.za/sites/www.westerncape.gov.za/files/wcdmc_annual_report_ 16-17-_signed_copy.pdf (Accessed 10 April 2017).

RINGLER C, BRYAN E, HASSAN RM, ALEMU T and HILLESLAND M (2011) How can African agriculture adapt to climate change? Insights from Ethiopia and South Africa. Research Brief Series 15 International Food Policy Research Institute, Washington DC.
RIVER HEALTH PROGRAMME (2011) State of rivers report: Rivers of the Breede Water Management Area. Department of Water Affairs, Western Cape, Republic of South Africa.

STATS SA (Statistics South Africa) (2012) Census 2011 Municipal report: Eastern Cape. Report No. 03-01-50. Statistics South Africa, Pretoria.

TROSKIE K and JOHNSTONE A (2016) Are boreholes a good investment? Southern Africa Borehole Water Journal Online September 2016

TSHUMA MC (2014) Understanding the small-scale agricultural sector as a precondition for promoting rural development in South Africa. Afr. J. Agric. Res. 9 (31) 2409-2418. https://doi.org/10.5897/ AJAR12.1631

TURPIE J and VISSER M (2013) The impact of climate change on South Africa's rural areas. Chapter 4 of Financial and Fiscal Commission: Submission for the 2013/14 Division of Revenue. Financial and Fiscal Commission, Cape Town. 100-160.

TWIGG J (2015) Disaster risk reduction. Good Practice Review 9, New edition. Overseas Development Institute, London. 368 pp.

UBISI NR, MAFONGOYA PL, KOLANISI U and JIRI O (2017) Smallholder farmer's perceived effects of climate change on crop production and household livelihoods in rural Limpopo province, South Africa. Change Adapt. Socio-Ecol. Syst. 3 (1) 27-38. https://doi. org/10.1515/cass-2017-0003

UDDIN MN, BOKELMANN W and ENTSMINGER JS (2014) Factors affecting farmers' adaptation strategies to environmental degradation and climate change effects: A farm level study in Bangladesh. Climate. 2 223-241. https://doi.org/10.3390/cli2040223

UNISDR/ITC/UNDP (2013) Protecting development from disasters: UNDP's Support to the Hyogo Framework for Action. Bureau for Crisis Prevention and Recovery, United Nations Development Programme, New York. 107 pp.

UNISDR (United Nations International Strategy for Disaster Reduction) (2004). Living with Risk - A Global Review of Disaster Reduction Initiatives. 2004 Edition - Volume 1. UNISDR, Geneva.

UNISDR (United Nations International Strategy for Disaster Reduction) (2007). Drought Risk Reduction Framework and Practices: Contributing to the Implementation of the Hyogo Framework for Action. United Nations Secretariat of the International Strategy for Disaster Reduction (UN/ISDR), Geneva. 98+vi pp.

UNISDR (United Nations International Strategy for Disaster Reduction) (2009) Progress in reducing disaster risk and implementing Hyogo Framework for Action in the Arab Region. Executive Summary, 2009. https://www.unisdr.org/files/14463 ImplementationoftheHyogoFrameworkEn.pdf (Accessed 12 May 2018).

UNISDR (United Nations International Strategy for Disaster Reduction) (2013) Disaster Risk Reduction in the United Nations: Roles, mandates and results of key UN entities. https://www.unisdr. org/files/32918_drrintheun2013.pdf

UNISDR (United Nations International Strategy for Disaster Reduction) (2015) Sendai framework for disaster risk reduction 2015 - 2030. United Nations Development Programme, Geneva.

VILAKAZI BS (2017) Indigenous knowledge systems available to conserve soil and water and their effects on physico-chemical properties on selected smallholder farms of Kwazulu-Natal. MSc thesis, University of KwaZulu-Natal.

VON LOEPER WJ, DRIMIE S and BLIGNAUT J (2018) The struggles of smallholder farmers: A cause of modern agricultural value chains in South Africa. In: Egilmez G (ed.) Agricultural Value Chain. IntechOpen. 161-180. https://doi.org/10.5772/intechopen.75710

WCDM (West Coast District Municipality) (2014) West Coast District Municipality Integrated Development Plan 2012/2016. Review 2, February 2014.

WCDM (West Coast District Municipality) (2018). Socio-economic profile. URL: https://www.westerncape.gov.za/provincialtreasury/ files/atoms/files/DC01\%20West\%20Coast\%20District\%202018\%20So cio-economic\%20Profile\%20\%28SEP-LG\%29 (Accessed 10 February 2018).

WCDOA (Western Cape Department of Agriculture) (2016) Western Cape climate change response framework and implementation plan for the agricultural sector - 2016. WCDOA, Elsenburg. 97 pp. 
WCDOA (Western Cape Department of Agriculture) (2017) Informing the Western Cape agricultural sector on the 2015-2017 drought. A Drought Fact Sheet, 23 November 2017. https://www.elsenburg.com/ sites/default/files/services-at-a-glance-forms/2017-12-13/drought-factsheet-final.pdf (Accessed 23 September 2018).
ZWANE EM (2019) Impact of climate change on primary agriculture, water sources and food security in Western Cape, South Africa. Jàmbá: J. Disaster Risk Stud. 11 (1) a562. https://doi.org/10.4102/ jamba.v11i1.562 